\title{
THE CONJUGATED, NON-PROTEIN, AMINO ACIDS OF PLASMA. V. A STUDY OF THE CLINICAL SIGNIFICANCE OF PEPTIDEMIA
}

\author{
By HALVOR N. CHRISTENSEN, DAVID G. DECKER, ELEANOR L. LYNCH, \\ THAYER M. MACKENZIE, AND JOHN H. POWERS \\ (From the Mary Imogene Bassett Hospital, Cooperstown, N. Y.)
}

(Received for publication March 19, 1947)

Peptidemia is a recurring concept of pathological chemistry which never has been either completely established or disproved. In a literature of about 100 papers only a few studies have been based upon methods which characterized the component measured as amino acids in conjugated forms ${ }^{1}$. The reported studies appear to indicate that intermediate protein degradation products frequently enter the blood in disease, so much so as to deprive their determination of diagnostic value.

Schweriner in 1920 (1) reported little if any peptides in mercuric chloride filtrates of normal blood but substantial amounts in neoplastic disease and in some types of liver disease. Blau (2) found elevated peptide nitrogen ( 1 to $8 \mathrm{mgm}$. per cent) in the blood in a number of diseases including 9 cases of hypertension. Becher and Herrman (3) found normal levels in carcinoma but high levels in severe renal insufficiency. Martens (4) reported concentrations of 8 to $13 \mathrm{mgm}$. per cent in severe hepatic and renal disease. Polonovski and Driesens (5) claimed that blood polypeptides were increased by as much as 4 times postoperatively, reaching a maximum 5 or 6 days after surgery. Hannaert and Wodon (6), Kalmykoff (7), Kotschneff (8), London and Kotschneff (9), and Martens (10) have reported evidence to show

\footnotetext{
1 Certain difficulties in terminology must be considered. The investigations reviewed here, and the present study as well, measured not peptides but amino acid conjugates which yield free amino acids upon hydrolysis. Although these conjugates usually have been supposed to be peptides, they may include proteins or such substances as hippuric acid. For simplicity we are using the inexact terms "peptides" and "peptide" nitrogen for these conjugates as determined by the procedures described here. Note that the ninhydrin method used by us yields all of the $\alpha$-amino groups of a typical peptide as "peptide" nitrogen, none as free $\alpha$-amino nitrogen, although one (the terminal) of these amino groups is not involved in a peptide bond. With the nitrous acid method, on the other hand, a dipeptide, for example, would yield one of its amino groups as free and the other as conjugated.
}

that ingested proteins were absorbed into the portal circulation partially as peptides and that the peptide content of the blood was modified upon flowing through the liver.

The principal ideas as to the clinical significance of peptidemia may be classified as follows:

1. That peptidemia is characteristic of neoplastic disease.

2. That peptidemia occurs after surgery or trauma or in certain types of shock, presumably because during increased protein catabolism, intermediate protein split-products may be released into the blood stream. This does not necessarily follow. Only slight increases of blood peptides were observed in proteose intoxication (11) and in histamine shock (12) although protein catabolism was strongly accelerated. "Peptide intoxication" as a humoral syndrome occurring after surgery, trauma or burns, proposed by Polonovski and Driessens (5), has been supported by several investigations. Postoperative peptidemia has been suggested as a precipitating factor in intravascular clotting (13).

3. That peptidemia occurs in hepatic disease, presumably because of the loss of a supposed hepatic function of clearing peptides from the blood.

4. That protein degradation products in the blood stream may be toxic and etiological agents in a number of diseases, including :

(a) hypertension $(2,14)$,

(b) toxemias of pregnancy (15),

(c) intestinal strangulation.

Whipple, Rodenbaugh, and Kilgore (16) concluded that the toxic agent accumulating in closed intestinal loops was a primary heteroproteose. De Negri (17) reported that ligature of the mesentric arteries of dogs gave large increases of blood polypeptides. His analytical method was not specific, however. We have not considered 
here the numerous other studies which have attempted to measure peptides by the difference in content of nitrogen (or of substances chromogenic with Folin's phenol reagent) in 2 types of filtrates of blood:

Even among those studies which have employed methods possessing some degree of specificity for conjugated amino acids, highly inconsistent results have been obtained for the normal levels of blood. These results have been tabulated elsewhere (18) together with a brief statement of the methods employed. Three factors have reduced largely the validity of such studies:

1. Inadequate deproteinizing procedures. Tungstic acid, picric acid and trichloroacetic acid, especially the latter in low concentration, all leave in solution non-dialyzable amino acid conjugates, presumably proteins (19). Dialysis of plasma must be very brief if proteolysis is to be avoided.

2. Analysis of serum or defibrinated blood. "Peptides" are formed in the course of clotting (19).

3. Analysis of whole blood. Erythrocyte glutathione contributes a major part of blood peptides. Apparent changes of blood peptides may arise from changes in hematocrit or from differences in the recovery of glutathione in blood filtrates (18).

In addition, the incomplete specificities of the analytical procedures, especially of the Folin amino acid method in its unmodified form, have probably contributed to the non-agreement.

Undetermined nitrogen in azotemia. In many cases of azotemia, notably "irreversible" azotemia following severe burns (20 to 22 ), a substantial part of the non-protein nitrogen has not been identified. The possibility frequently has been suggested that peptides might account for much of the unidentified nitrogen.

In brief, there is a wealth of ideas as to the pathological significance of peptidemia, but the experimental support is poor because of the inadequacy of the chemical procedures used. We have investigated the question employing the manometric ninhydrin procedure for amino acids, and using for the removal of proteins a combination of chemical deproteinization and dialysis (19). Such elevations of plasma "peptides" as we observed in a varied group of diseases were by no means as large as those previously reported, and were not sufficiently remarkable to give the determination diagnostic value, nor to contribute largely to the undetermined non-protein nitrogen of plasma.

\section{EXPERIMENTAL}

Plasma from heparinized venous blood (from fasting subjects except as indicated) was at once diluted with 4 volumes of redistilled water, and 5 volumes of dilute tungstic acid (23) or of 5 per cent trichloroacetic acid were added slowly. After 30 minutes the suspensions were centrifuged and the supernatant solution filtered. Free $\alpha$-amino nitrogen was determined promptly upon 6 to 8-ml. aliquots of the tungstic acid filtrates at $\mathrm{pH} 2.5$, or upon picric acid filtrates, by the manometric ninhydrin procedure (24). The result was corrected for the urea found present, except when a high urea concentration was anticipated, in which case urea was removed by urease.

A 30- to 50-ml. aliquot of the tungstic acid filtrate was dialyzed in a $3 / 4$-inch cellophane. tube against a single measured portion ( 60 to $80 \mathrm{ml}$ ) of redistilled water for 24 hours at $5^{\circ} \mathrm{C}$. on a slowly rotating wheel. Trichloroacetic acid filtrates were first freed of trichloroacetic acid by ether extraction (18), concentrated in vacuum, made to $25 \mathrm{ml}$. and a $24-\mathrm{ml}$. aliquot likewise dialyzed. A maximal aliquot of the dialysate was concentrated and hydrolyzed in a sealed tube at $110^{\circ} \mathrm{C}$. for 24 hours in $4 \mathrm{~N}$ hydrochloric acid. The hydrolysate was taken to dryness in vacuo, remoistened and dried again, $10 \mathrm{ml}$. of water added, and $3-\mathrm{ml}$. aliquots of the resultant solution were analyzed for $\alpha$-amino nitrogen at $\mathrm{pH} 2.5$. The difference in the 2 analyses (total diffusible $\alpha$-amino nitrogen minus free $\alpha$-amino nitrogen) is the conjugated diffusible $\alpha$-amino nitrogen, due to peptides and other amino acid conjugates. It is for this category that the term "peptide" nitrogen is used here, with the qualifications already noted. 1

\section{RESULTS}

Normal concentrations. Twenty-one tungstic acid filtrates of plasma from persons in the postabsorptive state contained an average of $0.9 \mathrm{mgm}$. per cent of conjugated $\alpha$-amino nitrogen (18). Such filtrates, however, contained from 0.2 to 0.5 mgm. per cent of conjugated $\alpha$-amino nitrogen which was not dialyzable, this presumably being due to proteins (18). Six filtrates studied consecutively in June 1946 (19) contained no measurable dialyzable conjugates ("peptides"). Fourteen samples analyzed subsequently contained an average of $0.51 \mathrm{mgm}$. per cent (S.D. $=0.07$; range 0.08 to $0.89 \mathrm{mgm}$. per cent) of "peptide" nitrogen. One may conclude that "peptides" are usually but not invariably demonstrable. Trichloroacetic acid filtrates generally showed slightly 
higher concentrations of these "peptides" (range, from 0.0 to $1.5 \mathrm{mgm}$. per cent "peptide" nitrogen). Most of the difference, however, in the total nitrogen content of these 2 types of filtrates is due to protein.

TABLE I

Effect of the ingestion of milk or casein upon plasma amino acids

All filtrates prepared by tungstic acid. Dialysates of these filtrates were analyzed in experiments 6 to 10 . All normal subjects except experiment 6 .

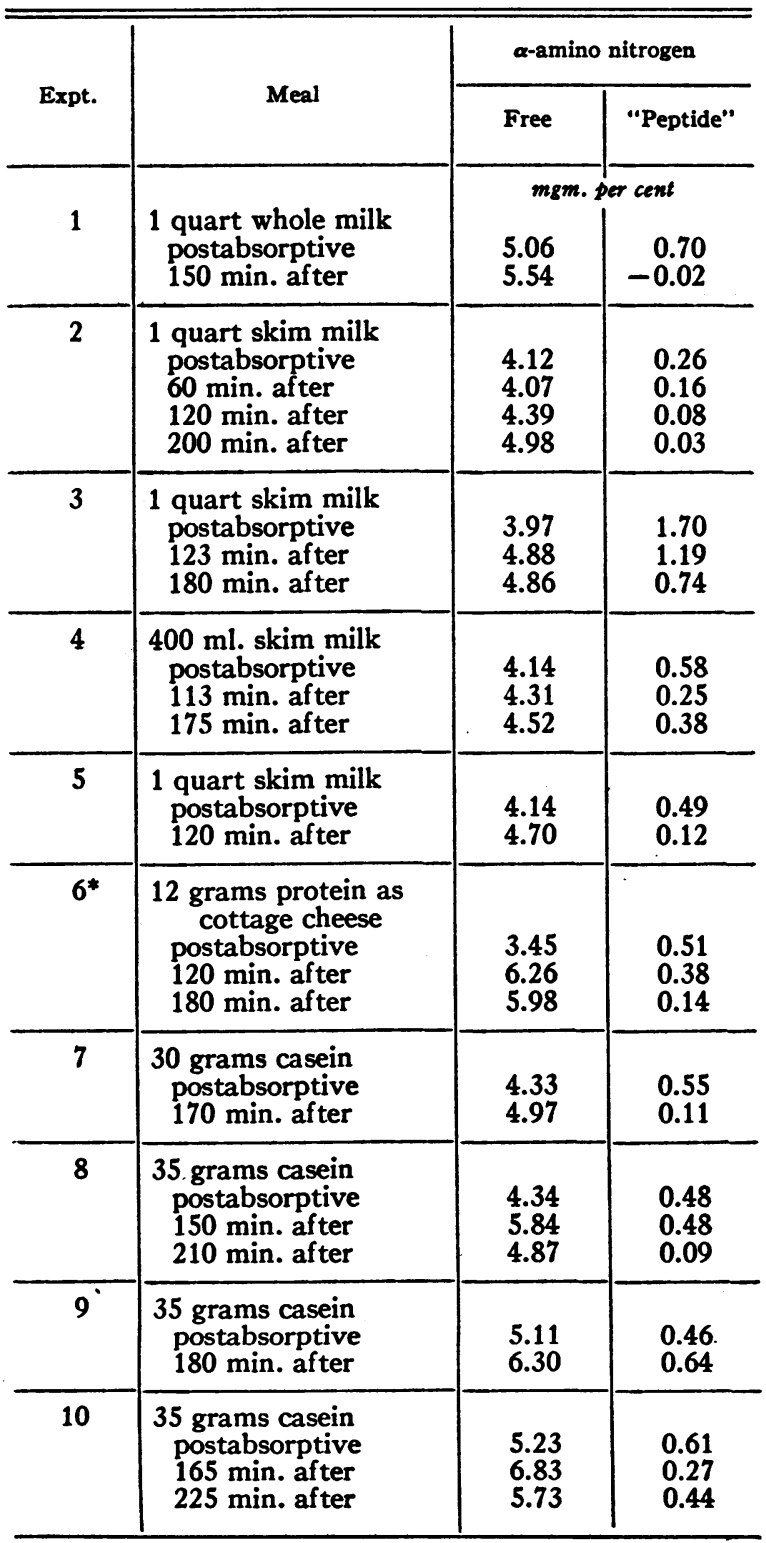

* Child, age 3.3 years, weight 26 pounds, cystic fibrosis of pancreas. When the test meal was 18 grams of gelatin the plasma amino acid $\mathrm{N}$ did not rise above $4.7 \mathrm{mgm}$. per cent.
As to the nature of these "peptides," glycine analyses indicated that hippuric acid, glutathione or serylglycylglycine made no large contribution. From acidified tungstic acid filtrates only small fractions of the conjugates were extracted by ethyl acetate.

Effect of protein ingestion. The peripheral venous plasma did not contain increased quantities of "peptides" after the ingestion of 100 grams of gelatin (25) or of 35 grams of egg white protein. The ingestion of a quart of milk, or of 35 grams of casein, led not to an increase but to a decrease in the "peptides" of plasma (Table I). This strange effect has been obtained 9 times in 10 experiments. This effect was not produced, in control experiments, by: ( $a$ ) continued fasting, ( $b$ ) the ingestion of 35 grams of starch, (c) drinking 1.5 liters of water in the course of an hour. No explanation of the effect of casein ingestion will be attempted.

Do surgical procedures lead to peptidemia? A preliminary study upon a patient exposed to very extensive abdominal surgery (dismantling of gastrojejunostomy, excision of marginal ulcer, hemicolectomy, transverse colostomy, enterostomy) gave the following values for "peptide" nitrogen in plasma samples taken 42, 69, and 110 hours after surgery:

(a) Undialyzed tungstic acid filtrate, $0.25,0.34$, $0.8 \mathrm{mgm}$. per cent.

(b) Undialyzed trichloroacetic acid filtrate, 0.84 , 0.80, 2.0 mgm. per cent.

Detailed study (Table II) of a group of patients exposed to various major surgical procedures failed to show any definite effect upon the "peptides" of plasma (although the free amino acids were always reduced [26]) or upon the urinary excretion of free or conjugated amino acids. The preoperative and postoperative concentrations of plasma "peptides" were somewhat higher than the average for normal subjects, but not outside the normal range. The increased protein catabolism which occurs postoperatively apparently does not result in the appearance of increased amounts of intermediate degradation products in the plasma.

Peptidemia in various diseases. Table III summarizes our observations upon patients with various diseases. Peptidemia did not appear to be characteristic of neoplastic diseases, hepatic dis- 
TABLE II

Effect of surgery upon free and conjugated amino acids of plasma and urine

\begin{tabular}{|c|c|c|c|c|c|c|c|c|c|c|}
\hline \multirow{2}{*}{ Surgical procedure } & \multirow{2}{*}{$\alpha$-amino $\mathrm{N}$} & \multicolumn{7}{|c|}{$\begin{array}{c}\text { Plasma } \\
\text { Interval after surgery }\end{array}$} & \multicolumn{2}{|c|}{ Urine } \\
\hline & & Preopt. & Immed. & 1 day & 2 days & 4 days & 7 days & 10 days & Preopt. & Postop.* \\
\hline $\begin{array}{l}\text { Carcinoma of sigmoid colon: } \\
\text { Resection, sigmoidoscopy, } \\
\text { exteriorization of sigmoid }\end{array}$ & $\begin{array}{l}\text { Free } \\
\text { Peptides } \\
\text { Peptides } †\end{array}$ & $\begin{array}{l}4.96 \\
1.68 \\
0.75\end{array}$ & $\begin{array}{l}3.93 \\
0.76\end{array}$ & $\begin{array}{l}4.28 \\
0.66\end{array}$ & $\begin{array}{l}\text { m. per ce } \\
3.84 \\
1.40 \\
0.98\end{array}$ & $\begin{array}{l}4.50 \\
1.14 \\
0.87\end{array}$ & $\begin{array}{l}4.72 \\
1.40 \\
0.25\end{array}$ & $\begin{array}{l}4.34 \\
0.90\end{array}$ & $\begin{array}{l}\operatorname{mgm} . \\
7.27 \\
5.90\end{array}$ & $\begin{array}{l}\text { er hour } \\
9.50 \\
5.80\end{array}$ \\
\hline $\begin{array}{l}\text { Open reduction of commi- } \\
\text { nuted fracture of tibia with } \\
\text { application of bone plate }\end{array}$ & $\begin{array}{l}\text { Free } \\
\text { Peptides } \\
\text { Peptides } \dagger\end{array}$ & $\begin{array}{l}3.99 \\
0.41 \\
0.55\end{array}$ & $\begin{array}{l}2.93 \\
0.77 \\
0.68\end{array}$ & $\begin{array}{l}2.79 \\
0.47 \\
0.80\end{array}$ & $\begin{array}{l}4.08 \\
0.73 \\
0.79\end{array}$ & $\begin{array}{l}3.76 \\
1.02 \\
0.87\end{array}$ & $\begin{array}{l}3.60 \\
0.44\end{array}$ & & $\begin{array}{l}3.17 \\
4.10\end{array}$ & $\begin{array}{l}5.09 \\
7.10\end{array}$ \\
\hline $\begin{array}{l}\text { Open reduction of fracture of } \\
\text { radius and ulna with appli- } \\
\text { cation of bone plate }\end{array}$ & $\begin{array}{l}\text { Free } \\
\text { Peptides }\end{array}$ & $\begin{array}{l}4.18 \\
1.17\end{array}$ & $\begin{array}{l}2.98 \\
0.96\end{array}$ & $\begin{array}{l}4.08 \\
0.89\end{array}$ & $\begin{array}{l}3.60 \\
0.55\end{array}$ & $\begin{array}{l}4.20 \\
0.81\end{array}$ & & & $\begin{array}{l}4.81 \\
6.60\end{array}$ & $\begin{array}{l}5.83 \\
5.66\end{array}$ \\
\hline $\begin{array}{l}\text { Exploration of kidney, ure- } \\
\text { terotomy with removal of } \\
\text { stone }\end{array}$ & $\begin{array}{l}\text { Free } \\
\text { Peptides }\end{array}$ & $\begin{array}{l}3.92 \\
1.06\end{array}$ & & $\begin{array}{l}3.83 \\
0.50\end{array}$ & $\begin{array}{l}3.41 \\
0.74\end{array}$ & $\begin{array}{l}4.47 \\
0.79\end{array}$ & $\begin{array}{l}4.07 \\
0.58\end{array}$ & & $\begin{array}{l}4.98 \\
4.73\end{array}$ & $\begin{array}{l}4.36 \\
4.11\end{array}$ \\
\hline $\begin{array}{l}\text { Peritonitis with obstructive } \\
\text { symptoms; exploration }\end{array}$ & $\begin{array}{l}\text { Free } \\
\text { Peptides }\end{array}$ & $\begin{array}{l}3.3 \\
1.3\end{array}$ & $\begin{array}{l}3.28 \\
1.25\end{array}$ & & & & & & & \\
\hline $\begin{array}{l}\text { Carcinoma of rectum; bilat- } \\
\text { eral radical dissection of } \\
\text { inguinal lymph nodes }\end{array}$ & $\begin{array}{l}\text { Free } \\
\text { Peptides }\end{array}$ & $\begin{array}{l}4.69 \\
0.70\end{array}$ & $\begin{array}{l}2.42 \\
0.53\end{array}$ & $\begin{array}{l}2.63 \\
0.67\end{array}$ & $\begin{array}{l}2.93 \\
0.69\end{array}$ & $\begin{array}{l}3.44 \\
0.79\end{array}$ & $\begin{array}{l}3.78 \\
0.88\end{array}$ & $\begin{array}{l}3.87^{* *} \\
0.40\end{array}$ & $\begin{array}{r}6.86 \\
11.80\end{array}$ & $\begin{array}{l}6.94 \\
9.40\end{array}$ \\
\hline
\end{tabular}

* All urine excreted during a 72- to 96-hour period beginning just before the operation. The preoperative urines were collected during the preceding 12 hours.

$\dagger$ Tungstic acid filtrates of plasma. All other values for "peptide" $\mathrm{N}$ of plasma were determined upon 2.5 per cent trichloroacetic acid filtrates.

** Fourteenth day after surgery, free $\alpha$-amino N, 4.03 mgm. per cent; "peptide" N, 0.39 mgm. per cent.

ease, even if severe, of venous thrombosis, of severe burns without azotemia, or of a number of other conditions. Somewhat elevated values appeared to occur in the nephrotic syndrome, and also in some cases of azotemia, but no level above $2.5 \mathrm{mgm}$. per cent of "peptide" nitrogen has been observed. While one cannot conclude that the rather small elevations observed in disease are without physiological significance, no indication of diagnostic value of the analysis has been obtained, nor do peptides and other conjugates appear to make any major contribution to the undetermined non-protein nitrogen of plasma.

Subjects showing the higher concentrations of "peptides" in the plasma did not regularly excrete larger quantities in the urine. On the other hand whenever the plasma peptide nitrogen is elevated by a few mgm. per cent by the intravenous injection of peptides (in the form of incomplete hydrolysates of protein) there is a massive peptiduria $(27,28)$. A dissimilarity is apparent in the nature of the "peptides" of plasma in the two situations.
Other body fluids. Several cerebrospinal fluid samples (by lumbar puncture) contained from 0.2 to $0.8 \mathrm{mgm}$. per cent of "peptide" nitrogen (Table IV). Tungstic acid, trichloroacetic acid and picric acid all left in solution a large fraction (15 to 50 per cent) of the protein of normal cerebrospinal fluid. Seminal plasma was unusually rich in free amino acids and in peptides, probably because of the presence of strong proteolytic activity, which led to the release of nearly $100 \mathrm{mgm}$. per cent of free amino acid nitrogen in 12 hours at $20^{\circ}$. Pathological accumulations of chest fluid, 'ascitic fluid, and synovial fluids appeared to contain "peptide" nitrogen in the range of 1 to $3 \mathrm{mgm}$. per cent.

\section{SUM MARY}

1. Factors which largely vitiate the validity of former determinations of blood peptides have been considered. The conjugated non-protein, amino acids (peptides plus other conjugates) of the plasma of normal persons and patients have been examined by procedures designed to avoid such factors. 
TABLE III

"Peptides" of plasma in various diseases

$\mathrm{TCA}=2.5$ per cent trichloroacetic acid

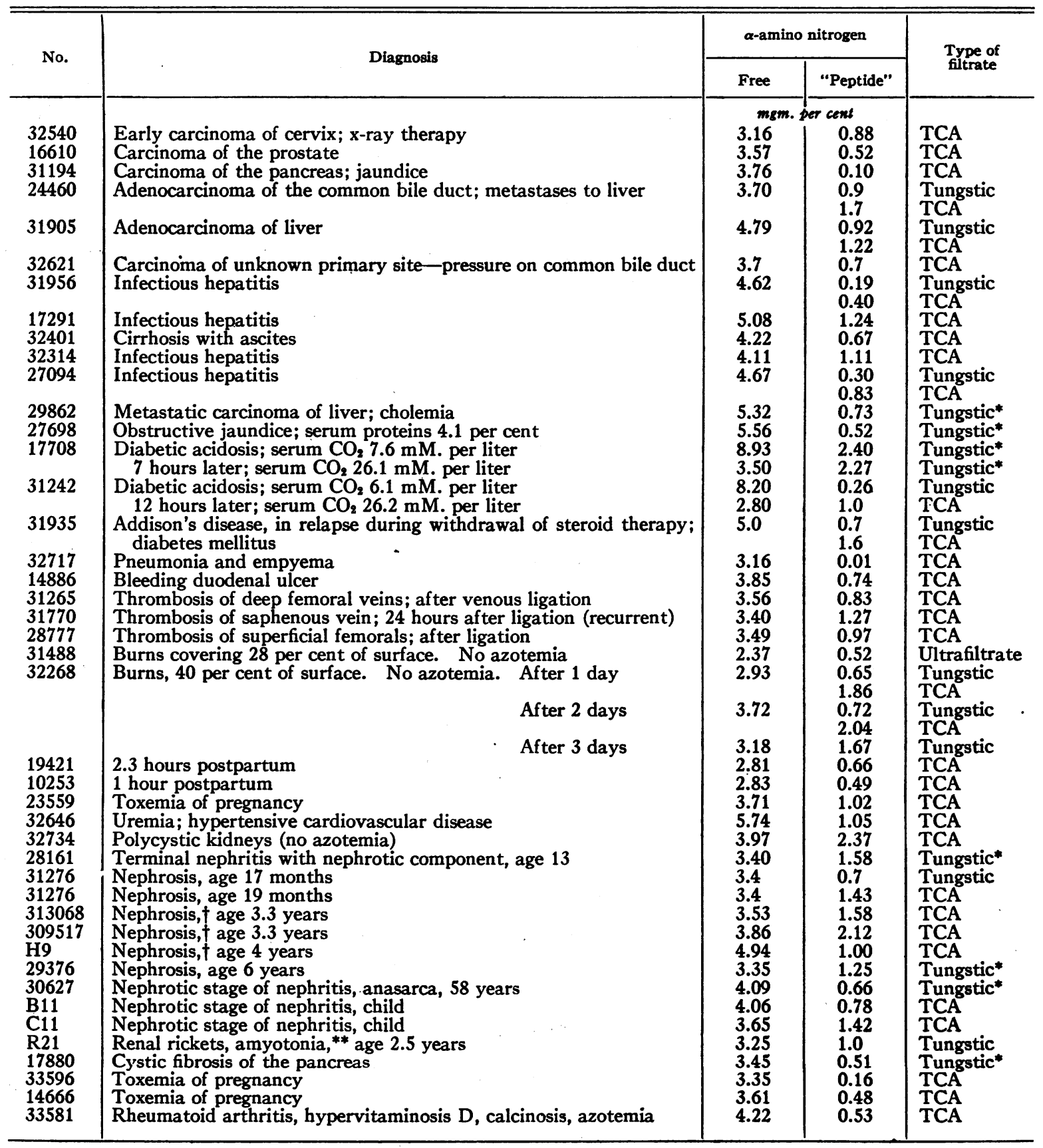

* Analyses upon undialyzed filtrates; hence, some protein presumably is included.

† Sample supplied by Dr. Gretchen Hutchens, Children's Hospital, Boston.

** Sample supplied by Dr. Nathan Talbot, Massachusetts General Hospital, Boston. The urinary excretion of free $\alpha$-amino acid nitrogen was $150 \mathrm{mgm}$. per day; of glycine nitrogen, $31 \mathrm{mgm}$. per day. 
TABLE IV

Amino acids and "peptides" of some body fluids

\begin{tabular}{|c|c|c|c|c|}
\hline \multirow{2}{*}{ No. } & \multirow{2}{*}{ Fluid; diagnosis } & \multicolumn{2}{|c|}{$\alpha$-amino nitrogen } & \multirow{2}{*}{$\begin{array}{l}\text { Type of } \\
\text { filtrate }\end{array}$} \\
\hline & & Free & "Peptide" & \\
\hline \multirow{2}{*}{$\begin{array}{ll}\text { L } & 27 \\
\text { J } 55\end{array}$} & \multirow{9}{*}{$\begin{array}{l}\text { Cerebrospinal fluid, normal } \\
\text { Cerebrospinal fuid, hydro- } \\
\text { cephalus, ventricular tap } \\
\text { Cerebrospinal fuid, normal } \\
\text { Cerebrospinal fuid, meningo- } \\
\text { coccal meningitis } \\
\text { Cerebrospinal fluid, normal } \\
\text { Seminal plasma } \\
\text { Same, after } 12 \text { hours at } 20^{\circ} \\
\text { Chest fluid, measles, pleurisy } \\
\text { Chest fluid, constrictive peri- } \\
\text { carditis 7/9 } \\
\text { Chest fluid, constrictive peri- } \\
\text { carditis 7i19 } \\
\text { Ascitic fluid. sec. carcinoma of } \\
\text { peritoneum } \\
\text { Synovial fuid, from knee. } \\
\text { rheumatoid arthritis }\end{array}$} & 1.41 & 0.8 & TCA \\
\hline & & 1.04 & 0.10 & TCA \\
\hline $\begin{array}{ll}\mathbf{K} & 54 \\
\mathbf{K} & 50\end{array}$ & & 1.16 & 0.48 & TCA \\
\hline $\begin{array}{l}\text { M } 8 \\
\text { E } 72\end{array}$ & & $\begin{array}{r}1.06 \\
1.80 \\
15.8 *\end{array}$ & $\begin{array}{r}0.74 \\
0.20 \\
14.0^{*}\end{array}$ & $\begin{array}{l}\text { TCA } \\
\text { Dialysate } \\
\text { Picric }\end{array}$ \\
\hline $\begin{array}{l}\text { N } 21 \\
\text { K } 32\end{array}$ & & $\begin{array}{c}103.6 \\
1.52\end{array}$ & & $\begin{array}{l}\text { Picric } \\
\text { Picric }\end{array}$ \\
\hline & & 4.73 & 1.31 & TCA \\
\hline & & 3.34 & 2.68 & TCA \\
\hline K 43 & & 3.83 & 0.91 & TCA \\
\hline J 33 & & & & TCA \\
\hline
\end{tabular}

* Three other experiments gave similar findings. Free glycine $\mathrm{N} 0.62 \mathrm{mgm}$. per cent; alanine $\mathrm{N} 1.4 \mathrm{mgm}$. per cent; little, if any, glutamine.

2. Tungstic acid filtrates of the plasma of normal fasting persons contained usually less than $1 \mathrm{mgm}$. per cent of conjugated, non-protein, amino acid nitrogen, and in some cases the concentration was too small to be measured. Protein ingestion did not increase the concentration of conjugates; in fact, milk or casein produced decreases.

3. Surgical procedures failed to produce increases of the "peptides" of plasma, nor were significant changes produced in the urinary excretion of free or conjugated amino acids.

4. While the plasma of patients with a variety of diseases contained as an average somewhat more amino acid conjugates than the plasma of normal persons most of the values were not outside the range encountered in normal persons. Elevated values did not appear to be characteristic of neoplastic disease, hepatic disease, or venous thrombosis. Somewhat elevated values were observed in nephrosis, but no value above $2.5 \mathrm{mgm}$. per cent of "peptide" nitrogen has been observed.

5. The free and conjugated amino acids of a few other body fluids have been reported.

\section{BIBLIOGRAPHY}

1. Schweriner, F., Der anteil der Polypeptide und aminosauren am reststickstoff des Blutes. Z. exp. Path. u. Therap., 1920, 21, 129.

2. Blau, N. F., The amino acid nitrogen of the blood. III. A study of the occurrence of peptide nitrogen in the blood. J. Biol. Chem., 1923, 56, 873.
3. Becher, E., and Herrmann, E., Der freie und gebundene Aminostickstoff im enteiweissten Blut und Gewebe unter normalen und pathologischen Verhältnissen; III. Befunde im blut bei Krankheiten, insbesondere bei Leberkrankheiten. IV. der freie und gebundene Amino- $\mathrm{N}$ im enteiweissten Blut bei essentieller Hypertonie und Nierenkrankheiten. Deutsches Arch. f. klin. Med., 1932, 173, 1, 23.

4. Martens, R., Contribution à l'étude de l'azote peptidique dans le sang. Bull. Soc. chim. biol., 1928, 10, 1336.

5. Polonovski, M., and Driessens, J., L'hyperpolypeptidémie et l'azotémie postopératoires in chirurgie générale. Compt. rend. Soc. de biol., 1931, 107. 324.

6. Hannaert, L., and Wodon, R., Contribution a l'étude de hemoclasie digestive. Compt. rend soc. Biol., 1923, 88, 636.

7. Kalmykoff, M. P., Abbau im darm und aufbau in der leber bei eiweissresorption. Arch. f. d. ges. Physiol., 1924, 205, 493.

8. Kotschneff, N., Weitere Untersuchungen über das Verhalten verschiedener Eiweissabbauprodukte im Intermediargebeit nach Versuchen an angiostomierten Hunden. Arch. f. d. ges. Physiol., 1928, 218, 635.

9. London, E. S., and Kotschneff, N. P., In welcher form wird nahrungseiweiss resorbiert? Z. Physiol. Chem., 1934, 228, 235.

10. Martens, R., Rôle de la paroi intestinale et du foie lors de la résorption des produits de digestion des protéides. Bull. Soc. chim. biol., 1931, 13, 1187.

11. Whipple, G. H., and Van Slyke, D. D., Proteose intoxications and injury of body protein. III. Toxic protein catabolism and its influence upon the nonprotein nitrogen partition of the blood. J. Exper. Med., 1918, 28, 213.

12. Hiller, A., The effects of histamine on protein catabolism. J. Biol. Chem., 1926, 68, 847.

13. Ochsner, A., Intravenous clotting. Surgery, 1945, 17, 240.

14. Jackson, H., Jr., Sherwood, D. W., and Moore, O. J., The blood peptide nitrogen in arterial hypertension. J. Biol. Chem., 1927, 74, 231.

15. Schlossmann, H., Der gehalt des blutes in aminosauren und polypetiden in schwangerschaft, geburt und wochenbett mit besonderer berucksichtigung der schwangerschaft toxamien. Z. ges. exptl. med., $1925,47,487$.

16. Whipple, G. H., Rodenbaugh, F. H., and Kilgore, A. R., Intestinal obstruction; proteose intoxication. J. Exper. Med., 1916, 23, 123.

17. De Negri, L., Dei polypeptidi e di altre frazioni azotate nell'occlusione e necrosi dell'intestino. Riv. patol. sper., 1938, 21, 15.

18. Christensen, H. N., and Lynch, E. L., The conjugated, non-protein amino acids of plasma. I. Postabsorptive concentrations of human plasma, serum and erythrocytes. J. Biol. Chem., 1946, 163, 741. 
19. Christensen, H. N., and Lynch, E. L., The conjugated non-protein amino acids of plasma. II. A study of deproteinizing techniques. J. Biol. Chem., 1946, $166,87$.

20. Taylor, F. H. L., Levenson, S. M., Davidson, C. S., and Adams, M. A., Abnormal nitrogen metabolism in patients with thermal burns. New England J. Med., 1943, 229, 855.

21. Walker, J., Jr., A study of the azotemia observed after severe burns. Surgery, 1946, 19, 825.

22. Rosenthal, O., and McCarthy, M. D., Post-burn azotemia, its characteristics and relationship to the severity of thermal injury. Am. J. Physiol., 1947, $148,365$.

23. Van Slyke, D. D., and Hawkins, J. A., A gasometric method for the determination of reducing sugars, and its application to analysis of blood and urine. J. Biol. Chem., 1928, 79, 739.

24. Hamilton, P. B., and Van Slyke, D. D., The gasometric determination of free amino acids in blood filtrates by the ninhydrin-carbon dioxide method. J. Biol. Chem., 1943, 150, 231.

25. Christensen, H. N., Cooper, P. F., Jr., Johnson, R. D., and Lynch, E. L., Glycine and alanine concentrations of body fluids; experimental modification. J. Biol. Chem., 1947, 168, 191.

26. Man, E. B., Bettcher, P. G., Cameron, C. M., and Peters, J. P., Plasma $\alpha$-amino acid nitrogen and serum lipids of surgical patients. J. Clin. Invest., 1946, 25, 701.

27. Christensen, H. N., Lynch, E. L., and Powers, J. H., The conjugated, non-protein, amino acids of plasma. III. Peptidemia and hyperpeptiduria as a result of the intravenous administration of partially hydrolyzed casein (amigen). J. Biol. Chem., 1946, 166, 649.

28. Christensen, H. N., Lynch, E. L., Decker, D. G., and Powers, J. H., The conjugated, non-protein, amino acids of plasma. IV. A difference in the utilization of the peptides of hydrolysates of fibrin and casein. J. Clin. Invest., 1947, 26, 849. 